\title{
REDES SOCIAIS DAS/NAS MIGRAÇÕES TECIDAS EM CONTEXTO DE VIDA E TRABALHO DE DOMÉSTICAS MIGRANTES
}

\author{
SOCIAL NETWORKS OF/IN MIGRATIONS WOVEN IN THE \\ CONTEXT OF LIFE AND WORK OF MIGRANT DOMESTIC
}

\author{
Guélmer Júnior Almeida Faria ${ }^{1}$
}

\begin{abstract}
RESUMO: O artigo trata das relações migratórias em um contexto de vida e trabalho e de como se manifestam as experiências de mulheres de comunidades rurais do norte de Minas Gerais para atuar no trabalho doméstico nas casas das famílias de classe média e alta nos grandes centros urbanos. Em termos metodológicos, o artigo apresenta uma pesquisa qualitativa realizada com entrevistas de História Oral, na qual busca-se compreender as estratégias de reprodução da vida dessas trabalhadoras domésticas migrantes, que estão calcadas em redes sociais das/nas migrações. A análise revela os mecanismos usados pelas domésticas migrantes e de suas famílias para superar dificuldades na mobilidade pelo trabalho, utilizando as redes sociais que acionam laços de família, pertencimento, confiança, cooperação e identidade.
\end{abstract}

PALAVRAS-CHAVES: Trabalho Doméstico; Migrações Rurais-Urbanas; Mulheres; Redes Sociais.

ABSTRACT: The article deals with migratory relations in a context of life and work and how they manifest themselves as experiences of women from rural communities in northern Minas Gerais to work in domestic work in the homes of middle and upper class families in large urban centers. In methodological terms, the article presents a qualitative research carried out with an Oral History report, in which it seeks to understand as a strategy for reproducing the lives of these migrant domestic workers, who are based on social networks of/in migrations. The analysis reveals the mechanisms used by migrant families and their families to overcome difficulties in mobility through work, using social networks that trigger family ties, belonging, trust, cooperation and identity.

KEYWORDS: Housework; Rural-Urban Migration; Women; Social Networks.

\footnotetext{
* Esse artigo é produto da tese de doutorado defendida na Universidade Estadual de Montes Claros (UNIMONTES) em 2019 financiada pela CAPES no Programa de Pós-Graduação em Desenvolvimento Social.

${ }^{1}$ Bolsista de Pós Doutorado UFV (PNPD/CAPES). Doutor em Desenvolvimento Social (UNIMONTES). E-mail: guelmerjrf@gmail.com
} 


\section{Introdução}

Partindo de um acontecimento social muito presente no cotidiano das comunidades rurais da região norte de Minas Gerais - que é o recrutamento de trabalhadoras para os grandes centros, como, Brasília/ DF, Belo Horizonte/ MG e São Paulo/ SP, para atuarem como domésticas -, o objetivo deste artigo é identificar as dificuldades enfrentadas pelas mulheres migrantes rurais; trabalhadoras domésticas nas relações sociais estabelecidas em seu contexto de vida e trabalho. Pesquisas recentes têm destacado o crescimento e a relevância das mulheres, sobretudo trabalhadoras, nos circuitos migratórios contemporâneos.

Ao analisar o nexo entre fluxos migratórios e modalidades de prestação de cuidados no Brasil, o local de prestação dos cuidados têm sido os domicílios particulares. O perfil étnico é composto por mulheres negras, 67\% (PNAD, 2014). Sobre as migrantes ainda pesam a informalidade das relações trabalhistas. O trabalho doméstico remunerado no Brasil é presente em todo o território nacional, ocorrendo de forma concentrada no ambiente urbano e nos estados com maior concentração populacional. No caso do volume de domésticas por estados da Federação, quase metade delas $(45,8 \%)$ encontra-se em três estados da Região Sudeste: São Paulo (23,9\%), Minas Gerais $(11,6 \%)$ e Rio de Janeiro (10,3\%), sendo que só em São Paulo são 1,5 milhões de domésticas (COSTA, 2017).

Em 2018, no entanto, as diaristas ultrapassaram as demais proporções, com 42,1\% do total de trabalhadoras domésticas (DIEESE, 2019). Nas regiões Norte e Jequitinhonha/ Mucuri do Estado de Minas Gerais, chama atenção o maior grau de informalidade do trabalho doméstico: as domésticas mensalistas sem carteira assinada representam mais da metade dessas trabalhadoras (BOLETIM PAD-MG, 2011). No entanto,

[...] em função do histórico de subordinação, da falta de capacitação profissional e formação educacional, que constituem alguns dos aspectos da vulnerabilidade social em 
que estão inseridas as domésticas no país, estas enfrentam a autonomia em uma significativa desvantagem social (COSTA, 2017: 189).

Dessa forma, o trabalho doméstico tem se caracterizado por ser exercido por mulheres de baixa escolaridade, negras, mais velhas e com maiores responsabilidades na condução de suas próprias famílias, nas quais a proporção de mulheres chefes aumentou consideravelmente (de 15,1\%, em 1992, para 41,8\%, em 2018). Chama atenção o fato de $87,8 \%$ das mensalistas sem carteira assinada não terem contribuído para a previdência social, em 2018. Situação semelhante é verificada entre as diaristas: 79,1\% delas não contribuíram para a previdência, no mesmo período (DIEESE, 2019).

Segundo Suely Kofes (1990: 93-94), “[...] as relações entre classes e culturas diferentes e desiguais supõem relações políticas, mesmo quando se dão no que se designa privado". Sobre as relações de poder, Kofes (1990) adverte para a hierarquia das relações de gênero presente no encontro entre patroas e domésticas: uma mulher de classe alta ou média subordinando uma outra mulher de classe inferior. As relações de poder tendem a ser mera reprodução da sociedade patriarcal baseada em quem manda e quem obedece, uma desigualdade constitutiva onde afetividade, confiança e distanciamento se mesclam e expressam as entrelaçadas relações do trabalho doméstico.

As trabalhadoras domésticas iniciam sua carreira cedo com 12, 13 anos de idade, na qual começam trabalhando em sua própria cidade ou em cidades vizinhas à sua, no interior, para, depois, chegarem até as capitais. Mesmo jovens, quase sempre passam por diversas residências, comprovando a alta rotatividade da ocupação. Na maioria dos casos, a iniciação na atividade se dá por contatos primários: uma amiga que já está na cidade grande ou um empregador originário da mesma cidade da jovem que visita sempre este local, ex-patroas que acabam sendo uma espécie de intermediárias, criando redes de contatos (MOTTA, 1977). E uma que vai, leva outra, que leva outra e constrói a rede.

Há, portanto, distinções quando se fala de redes sociais e migração: redes sociais na migração e redes sociais $d a$ migração. A primeira está ligada ao 
conteúdo da migrante e suas diversas interações presentes no processo social da migração (interpessoal). Já a segunda vincula-se aos recursos disponíveis para agir em contextos de deslocamento, tais como: capital social, capital migratório e cultura migratória ${ }^{2}$.

Segundo Chaney e Garcia Castro (1989), as trabalhadoras domésticas são recrutadas, em geral, entre mulheres pobres, com baixíssimos níveis de escolaridade, que migram de cidades ou comunidades rurais menores para os grandes centros urbanos. São de origem étnica discriminada e sua cultura, linguagem, costumes, vestimentas e raças, são consideradas inferiores. De acordo com Rosana Santos (2009: 41):

[...] explicita que o trabalho doméstico realizado de diversas maneiras, seja em residências particulares de forma constante ou intermitentes, há muito absorve a mão de obra feminina no Brasil, estando estreitamente ligado ao movimento migratório, interno e externo.

Segundo Neto e Nazareth (2012), a representatividade com que as moças vêm aparecendo nos números e nas discussões sobre migração no mundo globalizado faz com que muitos especialistas falem de uma feminização dos fluxos migratórios ou deslocamentos populacionais e, mais recentemente, de mobilidade sociolaboral. Isso torna necessária uma ponderação interna sobre as peculiaridades da migração feminina.

Inevitavelmente, na região norte de Minas Gerais, considerada como "região mineira do Nordeste", outorga-lhe pautas de desenvolvimento calcados na mercantilização da terra, assalariamento das relações de trabalho e projetos de mineração (excludente, agro-minero-exportador). As consequências disso são, geralmente, o chamado "deslocamento compulsório" (GUEDES, 2012), migração forçada de grupos e comunidades. Tal fato impacta

\footnotetext{
${ }^{2}$ Para Truzzi (2008), as migrações locais parecem, assim, ter contribuído para a formação de uma cultura migratória. Cito a região de Governador Valadares, o sertão Norte Mineiro, como exemplos de redes migratórias baseadas em relações de parentesco, amigos e conterrâneos. A cultura de migrar facilitou o deslocamento interno no Brasil, em que parentes, conterrâneos e ex-migrantes agem como uma corrente transmissora de informações, recursos, capital migratório (know-how da migração) alimentada pelo capital social de reciprocidade e solidariedade.
} 
sobremaneira a vida das mulheres e das jovens da região, pois, as desigualdades de gêneros, nesse contexto, se acentuam.

A historiografia regional do norte de Minas Gerais apresenta um diagnóstico, que segundo Pereira (2007: 226) “identifica-o como uma área subdesenvolvida, assolada pelos fatores climáticos, explorada por outras regiões e desassistida pelo poder público. Ao construir tais imagens, faz emergir o discurso de vítima e encobre as clivagens sociais". Discorrer com essas interpretações possibilita recompor as trajetórias de vida e trabalho. Pondero que o deslocamento laboral dessas trabalhadoras domésticas não se sustente apenas na tríade: pobreza, falta de oportunidades e o desemprego.

$\mathrm{O}$ norte de Minas possui características muito similares à região Nordeste. Paula (2003) a denominou como região mineira do Nordeste, elencando os vários processos sofridos pela dinâmica da ocupação, desenvolvimento e organização produtiva. Destacam-se as políticas de desenvolvimento advindas da criação da Superintendência do Desenvolvimento do Nordeste (SUDENE) ${ }^{3}$, a ocupação e expansão da pecuária bovina extensiva e a disponibilidade de terras livres e os novos projetos de desenvolvimento, calcados na exploração de recursos naturais, reflorestamento e industrialização. É, portanto, o desenvolvimento do capitalismo e a intensificação do processo de industrialização via urbanização que tecem os meandros das migrações internas no Norte de Minas Gerais.

Essas migrantes que partem rumo ao "sul", embora não constituindo maioria, apontam seus projetos de vida e a migração como uma possibilidade, na sua maioria jovens, veem a possibilidade de garantir a reprodução de suas vidas e de suas famílias e da permanência no meio rural através da suplementação de renda, geralmente das contribuições de trabalhos temporários nas cidades. Esse trabalho se concatena em atividades ligadas ao lugar social que essas mulheres ocupam na sociedade, tais como os de cuidados, diaristas, domésticas, acompanhantes, babás etc.

\footnotetext{
${ }^{3}$ Política pública de desenvolvimento regional criada em 1959, continuamente, sendo revisitada pelos planejadores do desenvolvimento para superar as desigualdades regionais dessa região, proveniente de sua geoeconomia, impactada pelo seu clima (seca) e território (aridez).
} 
Dados mais recentes, segundo a OIT (2016), revelam que no país havia sete milhões de pessoas empregadas no setor - o maior grupo no mundo. São três empregados(as) para cada grupo de 100 habitantes. E a liderança brasileira nesse ranking só é contestada pela informalidade que cresceu no período recente, assim como a quantidade de diaristas. Em 2013, mais de 30\% das trabalhadoras tinham carteira assinada, mas esse número sofreu novas quedas nos últimos anos, chegando a 28,3\% em 2018 (DIEESE, 2019). Em 2017, o trabalho doméstico respondeu por 6,8\% dos empregos no país e por 14,6\% dos empregos formais das mulheres (WENTZEL, 2018).

Ao abordar a migração de mulheres domésticas migrantes, justamente este tipo de mobilidade, parece necessário compreender que a migração é vista geralmente como alternativa para suplantar situações de pobreza e de exclusão do mercado de trabalho. As domésticas percebem isso muito antes de decidir migrar e assim o fazem por meio das redes de apoio entre elas ou acionam parentes, vizinhos, amigos e conterrâneos. Ehrenreich e Hochschild (2003) argumentam que há uma cadeia de cuidados, em que uma filha mais velha de uma família pobre cuida de seus irmãos, enquanto a mãe trabalha como doméstica cuidando dos filhos da patroa. Cada elo da cadeia expressa uma ecologia invisível de cuidados, uma trabalhadora de cuidados, dependendo de outra e assim por diante.

Esse trabalho é composto por essas notas introdutórias seguidas da seção sobre os caminhos metodológicos, através dos procedimentos e das entradas para realização da pesquisa. Examino na terceira seção a imigração feminina, redes sociais e as cadeias de cuidados. Na seção seguinte, faço um relato das condições de vida e trabalho das trabalhadoras domésticas do norte de Minas Gerais, com base em duas redes sociais das/nas migrações. Ao final, teço breves considerações e aponto algumas questões ainda pertinentes ao debate para futuras reflexões.

\section{Notas metodológicas}


Neste artigo, analiso os relatos orais de trabalhadoras domésticas, através da História Oral. Concebendo-a como metodologia que na visão de Portelli (2010: 182) "há elementos coletivos e compartilhados nessa história que são suficientes para justificar que a descrevamos como documento representativo da cultura da classe trabalhadora local". É dessa maneira que recorre-se à História Oral para entender como acontece a formação, manutenção e os conteúdos das redes sociais que dão suporte para que entendamos a construção da memória migratória das trabalhadoras domésticas. Busca-se compreender as estratégias de reprodução da vida dessas trabalhadoras domésticas migrantes, que estão calcadas em redes sociais das/nas migrações.

Ao mesmo tempo, recorre-se a técnica de entrevistas, como afirma Portelli (2010: 20), “a 'entre/vista', afinal, é uma troca de olhares. E bem mais do que outras formas de arte verbal, a história oral é um gênero multivocal, resultado do trabalho comum de uma pluralidade de autores em diálogo". Como também salienta Weiss (1994), as entrevistas em profundidades como técnica permite o acesso às observações de outras pessoas a respeito de um fato. Por meio da entrevista, pode-se aprender sobre lugares onde nunca se esteve e sobre experiências nunca vivenciadas. As entrevistas, por serem singularizadas, possibilitam ao pesquisador a obtenção de material "denso", único e com "profundidade", que expressam as manifestações de trabalhadoras domésticas em sintonia com as condições de classe, raça, gênero e em suas redes sociais, que são estratégias de ajuda mútua, solidariedade, apoio social, favor, confiança e cooperação. Esses fatores não são indissociáveis para analisar as relações migratórias dessas mulheres, pois, as desigualdades produzidas em torno deles, cotidianamente na vida delas, constroem pontes ou abismos assentados na diferenciação à classe social, raça e ao gênero.

A primeira ida a campo aconteceu entre os meses de março e agosto de 2017, com os pesquisadores(as) do projeto "Redes"4 que realizaram as

\footnotetext{
${ }^{4}$ A pesquisa é vinculada ao OPARÁ-MUTUM: Grupo de Estudos e Pesquisas sobre Migrações e Comunidades Tradicionais do rio São Francisco/CNPq e está inserida no projeto temático: "Do sertão para outros mundos": as redes de relações sociais nos processos migratórios para o
} 
entrevistas em profundidade nas cidades de São Francisco/ MG e Mirabela/ MG. Do caráter qualitativo deste estudo, estão embasadas nas entrevistas em profundidades que foram elaboradas de acordo com o interesse da pesquisa, mas que, no decorrer das conversas, se ampliaram. Foram realizadas entrevistas com domésticas migrantes oriundas dos dois munícipios mineiros pesquisados.

A partir da inserção empírica, identifico duas tipologias de redes dos circuitos migratórios de domésticas migrantes, isto é, uma rede de produção de movimentos, que se estende das comunidades rurais dos municípios mineiros de Mirabela e São Francisco para a capital de Minas Gerais, Belo Horizonte, e as capitais de São Paulo e Brasília (redes $d a$ migração). A outra rede são mulheres que estão em fase cumprida de migração, oriundas de cidades próximas e zonas rurais para a cidade de Montes Claros, residindo no bairro Village do Lago I (redes na migração). Assim, ao eleger os lócus de onde impulsionam as redes sociais da migração, é preciso contextualizar esses lugares de origem. Trata-se de uma região que atua como polo migratório, tanto interno quanto externo, seja na recepção ou na expulsão. Esse crescimento tem sido visto de forma acentuada em número de habitantes e em atividades econômicas, sobressaindo-se no setor de comércio, educação, saúde e prestação de serviços. Vimos no Norte de Minas Gerais, especificamente nos municípios de São Francisco e Mirabela, exemplos de espaços privilegiados para esse movimento migratório.

O município de Mirabela, segundo dados do IBGE (2010), possuía uma população de 13.042 habitantes. São Francisco, à época, continha uma população de 53.828 habitantes. Em termos migratórios, Fonseca (2015) constatou que São Francisco é um dos municípios que mais tem emigrantes, 11.206 pessoas emigraram no ano de 2010. O município de Mirabela possui 1.410 pessoas. Nota-se que as populações residentes femininas de ambos os municípios não registraram aumento, mantendo-se em média em 49\%. Esses dados devem ser interpretados levando-se em conta a estimativa populacional

trabalho do/no Norte de Minas Gerais", que conta com o apoio da FAPEMIG/CNPq e é coordenado pela Prof. ${ }^{\text {a Dr. }}{ }^{\text {a }}$ Andrea Maria Narciso Rocha de Paula. 
dos municípios - quanto maior o número de habitantes maior é a propensão em migrar. As populações rurais desses dois munícipios apresentam percentual maior que em muitos munícipios brasileiros.

Deve-se admitir que, diferente das décadas de 1980 e 1990, quando existia uma grande saída de pessoas do Norte de Minas ${ }^{5}$, entre os anos de 2018 e 2019, a região aumentou sua população em 8.714 habitantes (IBGE, 2010). Para Fonseca (2015) a população com potencial para migrar já se reduziu de tal forma que a tendência é não ter novos grandes fluxos. Tal característica pode ser identificada em muitos municípios do Norte de Minas que apresentam poucos habitantes, sendo a maioria de idosos.

No Quadro 1, a seguir, defino essas duas redes do ponto de vista de suas características migratórias, ocupação, redes da/na migração e sua espacialidade.

Quadro 1 - Características das duas redes pesquisadas

\begin{tabular}{|l|l|}
\hline \multicolumn{1}{|c|}{ Redes } & \multicolumn{1}{c|}{ Características } \\
\hline \hline \multirow{2}{*}{$\begin{array}{l}\text { Rede de domésticas do } \\
\text { bairro Village do Lago } \\
\text { I - Montes Claros/MG. }\end{array}$} & $\begin{array}{l}\text { - Etapa migratória cumprida. } \\
\text { - Experiência migratória ("sucesso"). } \\
\text { - Trabalho doméstico (mensalistas, diaristas). } \\
\text { reciprocidade). } \\
\text { - Espaço: Bairro. }\end{array}$ \\
\hline $\begin{array}{l}\text { Rede de domésticas de } \\
\text { munícipios } \\
\text { circunvizinhos } \\
\text { Montes Claros/MG. }\end{array}$ & $\begin{array}{l}\text { - Em fase migratória. } \\
\text { - Migração de retorno (fracasso e esperança), rotatividade. }\end{array}$ \\
\hline
\end{tabular}

Fonte: Dados da pesquisa (2018).

As oito participantes da pesquisa são mulheres escolhidas por informantes-chaves, famílias de origem e através dos testemunhos dos pesquisados. A construção das características das participantes obedeceu aos critérios: mulheres migrantes, com cinco anos ou mais de residência no local de destino, e que estão empregadas no trabalho doméstico com ou sem carteira

\footnotetext{
5 “A Mesorregião é estereotipada como espaço de perda migratória; todavia, as pesquisas sobre migrações no Norte de Minas não abrangem dados censitários que confirmem ou que refutem a perda migratória, além de não envolver os 89 municípios", segundo Fonseca (2015: 20).
} 
assinada, com idades compreendidas entre 40 a 58 anos. Procurou-se também identificar o local de origem, a idade de chegada e o ano, conforme descrito no Quadro 2.

Quadro 2 - Caracterização das trabalhadoras domésticas, 2017.

\begin{tabular}{|c|c|c|c|c|}
\hline Entrevistada & Idade & Local de nascimento & $\begin{array}{c}\text { Idade de } \\
\text { chegada }\end{array}$ & $\begin{array}{c}\text { Ano de } \\
\text { chegada }\end{array}$ \\
\hline \hline Marilda & 40 anos & Mirabela-MG & 16 anos & 1995 \\
\hline Denise & 58 anos & São Francisco-MG & 11 anos & 1972 \\
\hline Amélia & 45 anos & Mirabela-MG & 12 anos & 1986 \\
\hline Cecília & 50 anos & Mirabela-MG & 13 anos & 1982 \\
\hline Carmélia & 43 anos & São Francisco-MG & 15 anos & 1991 \\
\hline Magnólia & 44 anos & São Francisco-MG & 12 anos & 1987 \\
\hline Hortência & 41 anos & São João da Ponte- & 14 anos & 1992 \\
\hline Marinalva & 40 anos & Mirabela-MG & 16 anos & 1995 \\
\hline
\end{tabular}

Fonte: Dados da pesquisa (2018).

Esclareço, por fim, que os nomes das participantes foram modificados com a finalidade de manter o respeito, confidencialidade e sigilo das informações, para evitar constrangimentos e assegurar a confiança delas nos resultados de pesquisa. Os relatos orais foram transcritos sem correção de português objetivando destacá-los e dando voz ativa para as participantes. Ademais, as participantes foram informadas do Termo de Consentimento Livre e Esclarecido (TCLE), constando a gravação, o direito e uso de imagem e/ou informações por elas prestadas, lido e assinado, assim como a divulgação dos resultados com finalidades acadêmicas.

Imigração feminina, redes sociais e cadeias de cuidado

A discussão sobre a divisão sexual do trabalho a partir das dimensões de classe, gênero e raça permite olhar a divisão do trabalho, por exemplo, nos processos de migração de mulheres. As tarefas domésticas como 
de limpeza, como cuidar de idosos ou crianças e o âmbito migratório relacionam-se na medida em que reflete as dinâmicas de desigualdade entre as sociedades de emigração e as sociedades de migração (SAYAD, 1998).

Herrera (2012) pontua que a relação de gênero e migração se faz presente com a participação das mulheres nos fluxos de migração rural-urbana que transformaram as cidades durante o século $\mathrm{XX}$, momento de auge das políticas neoliberais implantadas na América Latina, e que serviram como um dos mecanismos através dos quais muitas mulheres ingressaram pela primeira vez ao mercado laboral, principalmente ao setor doméstico. Portanto, para a autora, rever estas relações permite entender que a migração não se instala como uma experiência totalmente nova sobre uma realidade de gênero fixa, senão que também faz parte de processos sociais, históricos, culturais e econômicos mais amplos.

Kofman e Raghuram (2012) alertam que os modelos de chaves de interpretação entre migração, gênero e trabalho de cuidado foram desenvolvidos com primazia do Sul para o Norte por experiências seletivas. Neste artigo, procura-se a partir de um exemplo regional refletir a diversidade e a dinâmica da migração e os circuitos de cuidados.

$\mathrm{O}$ cuidado tem sido discutido tanto no âmbito nacional e internacional de forma que sua análise foque em uma agenda de pesquisa sobre a transnacionalização do cuidado, por meio de cadeias globais de cuidado. Yeates (2012) admite que a pesquisa do cuidado reforça o trabalho de cuidado como trabalho de mulher; há certo privilégio da transnacionalização do cuidado e que suas as análises naturalizam o Estado-nação. Revelou-se que o foco das cadeias globais de cuidado, embora situando as mulheres em diversos contextos geográficos ao redor do mundo, trata-se de uma coordenada rede que fornece um bem social para a reprodução social e os resultados dessas interações, permite que sua leitura seja universal.

Nesse sentido, Gonzalez e Pardo (2017) referem que as complexas dinâmicas das desigualdades sociais emanam da configuração de estratégias contra hegemônicas que se expressam não só no efeito de migrar, senão 
também na criação de redes migratórias em torno do cuidado. As estratégias de sobrevivência geram processos de ação coletiva em rede, e as redes evidenciam novas configurações entre atores, contextos e vínculos nos quais se apoiam as relações do cuidado no contexto migratório.

Ao atrelá-lo aos estudos sobre migração das mulheres, Catarino e Oso (2000) evidenciam que o trabalho doméstico nas grandes cidades tem se nutrido, tradicionalmente, em diversos contextos geográficos e temporários, de mulheres jovens provenientes do meio rural. $\mathrm{O}$ estudo que tem abordado a migração feminina e o trabalho doméstico centra-se nos movimentos internos e no papel do trabalho doméstico como prática distinta para as classes que podem pagar por ele.

No entanto, quando se analisa pelo viés do gênero, Hagan (1998) demonstra que variação na estrutura das redes sociais influencia diferentemente a adaptação de homens e mulheres. Enquanto os homens se inserem em uma rede de controle da organização social do processo de trabalho, as mulheres submetem-se essencialmente ao trabalho doméstico e, em geral, moram no emprego. Assim, as redes sociais das mulheres giram em torno de redes fechadas ou encapsuladas. Essa situação acaba por influenciar a busca e a indicação de trabalho, bem como dificultar a mobilidade do trabalho, subjugando as trabalhadoras domésticas migrantes em um eterno refúgio, que é o trabalho doméstico.

Como exemplifica Lisboa (2007), as categorias de modalidades do trabalho doméstico - domésticas externas, mensalistas, faxineiras ou diaristas -, geralmente, são compostas por mulheres pobres, com filhos menores, morando nas periferias das grandes cidades, muitas vezes sem creche ou escolas em tempo integral para seus filhos. É nesse momento que as redes de apoio se fazem presente, garantindo acolhimento e estabelecimento no trabalho na cidade, o que, segundo Neto e Nazareth (2012), muitas vezes, são sua única forma de articulação com o mercado de trabalho, mesmo que o vivam de forma irregular e informal, sem as garantias previstas em lei. Atualmente, não oferecer 
alojamento para as empregadas é uma maneira de cortar gastos para a classe média.

Nesse sentido, no Brasil, as migrações internas ainda carecem de dados e de uma atenção dos(as) pesquisadores(as) para pensar a componente feminina e a extrínseca relação com o mercado de trabalho dessas mulheres. Lisboa (2006) chama a atenção para o nicho ocupacional reservado a essas mulheres. Serviços de faxineira e doméstica exerceram um papel importante na incorporação ao mercado de trabalho das mulheres no Brasil, porque constitui, culturalmente, o "lugar da mulher" e a execução dessas tarefas não exige nenhuma qualificação. A autora ainda evidencia que, historicamente, "em toda América Latina, dois terços das mulheres que migraram do campo para a cidade na década de 1990, em busca de melhores condições de vida, são atualmente trabalhadoras domésticas" (LISBOA, 2006: 158).

No Brasil, o trabalho doméstico é uma ocupação caracteristicamente feminina, que teve sua estirpe com a abolição da escravidão e a admissão das mulheres libertas como empregadas em "casas de família"6. Assim, o trabalho de mulheres carrega a cultura da desigualdade de gênero e, consequentemente, a naturalização de papéis e/ou características tidas como femininos-masculinas independente da classe social a que pertencem. Ou seja, mulheres, mesmo ocupando o espaço do trabalho assalariado, não deixam de ser responsabilizadas pelas tarefas da reprodução "em nome da natureza, do amor e do dever materno", do cuidado (HIRATA; KERGOAT, 2007).

Por fim, Baptista (2011) conclui que as transformações econômicas e sociais, associadas à globalização, contribuíram para a alteração do contexto da externalização do trabalho doméstico, transitando de um contexto de recrutamento interno para o trabalho doméstico, junto às classes mais baixas, para um contexto internacional, recorrendo a mulheres migrantes.

Ao voltarmos nossa análise para nosso lugar de pesquisa - o Norte de Minas Gerais -, quanto à emigração de mulheres e às relações de gênero,

\footnotetext{
${ }^{6}$ Essa expressão assume um marco da colonialidade (LUGONES, 2008) sobre as famílias de mulheres negras.
} 
não vemos expressiva diferença entre índices de migração de mulheres e homens, sendo 50,28\%, do sexo feminino, e 49,72\%, do sexo masculino, embora, as mulheres se sobressaem. Segundo dados da pesquisa de doutorado de Fonseca (2015), nas Microrregiões Grão Mogol, Montes Claros, Pirapora e Bocaiúva, predominaram emigrantes do sexo feminino. Todavia, as diferenças não são grandes. Apresentaram mais emigrantes do sexo masculino as Microrregiões de Salinas, Januária e Janaúba, mas a quantidade a mais também foi pouca, respectivamente, 104, 285 e 437 homens. Na Microrregião de Grão Mogol, foram registrados 173 emigrantes a mais do sexo feminino; na Microrregião de Bocaiúva, 237; na Microrregião de Pirapora, 372; e na Microrregião de Montes Claros, 742 (FONSECA, 2015).

Quanto à idade, os(as) emigrantes da Mesorregião do Norte de Minas, segundo faixa etária, foram encontradas de cinco até 102 anos. Considerados na faixa etária dos cinco até 19 anos (jovens), correspondem a 29,70\%; de 20 até 59 anos (adultos) chegam a 66,05\%, sendo a maioria tanto do sexo feminino quanto do masculino; com 60 anos ou mais (idosos) com 4,25\%.

$\mathrm{Na}$ interpretação dessa origem comum das domésticas abordadas, essa pode ser vista como uma prática cultural aliada à "cultura doméstica" e à "cultura migratória" das famílias pobres da região Norte de Minas Gerais, configurando-se, também, como uma tática de sobrevivência articulada às construções de gênero dos grupos familiares, desprovidos da zona rural e de redes sociais de apoio e ajuda mútua. Assim, o cenário do universo feminino migratório é adverso. As consequências das crises econômicas impactam as mulheres de maneira intensa, o que reproduz acentuadamente sua exclusão do mercado de trabalho fora do trabalho doméstico.

A transformação social e econômica da região, promovida por baixos índices de desenvolvimento social e humano, com projetos calcados na expulsão de povos de comunidades tradicionais, a falta de políticas públicas bem geridas, reforça a tese de alguns estudiosos, como Paula (2009) e Fonseca (2009) da criação de uma "cultura de migrar". Segundo Souza (2016), ela é transmitida através das gerações e pelas redes sociais. Essa cultura molda 
valores e atitudes, elevando o deslocamento a um "fato natural", oportuno para o sucesso financeiro pessoal e familiar. Por isso, as falas são carregadas de ressentimento, seja pela desigualdade, seja pela desvalorização do trabalho doméstico. Segundo Félix (2010: 46), a situação da “doméstica é uma relação singular de mulher trabalhando para outra mulher, na maioria dos casos, ambiente propício para os jogos de conflitos de gênero e classe, mesmo que seus participantes não percebam devido à cultura imprintada que torna o seu enredo como natural".

O trabalho doméstico, enquanto trabalho remunerado, no Brasil, foi conformado, na visão de Ávila (2016: 138):

[...] na imbricação das relações sociais de sexo, de raça e de classe. Uma análise crítica da trajetória do emprego doméstico evidencia que essa relação de trabalho foi tecida pelos fios da dominação e da exploração patriarcal e racista que estão incontornavelmente atados à formação do sistema capitalista.

Assim, gênero e raça são categorias centrais para tratar das oportunidades de vida das mulheres no contexto brasileiro em relação ao trabalho doméstico. De acordo com os dados da Pesquisa Nacional por Amostra de Domicílio (PNAD), no ano de 2014, 93\% dos postos de trabalho doméstico eram ocupados por mulheres no Brasil. Dessas, 67\% se autodenominavam negras. As domésticas representam, segundo Mori, Bernardino-Costa, Fleisher (2011: 16),

[...] aproximadamente sete milhões de trabalhadoras que menos têm direitos em relação a qualquer outra categoria profissional no país. E ainda, este tipo de trabalho reforça uma guetização profissional das mulheres em atividades ligadas aos cuidados, atividades essas muitas vezes entendidas como uma extensão das qualificações "naturais" das mulheres.

O contexto do universo das domésticas é marcado pela dívida social da sociedade escravista e patriarcal do século XIX. De acordo com Ferreira 
(2010: 340), "no Brasil o emprego doméstico vem de longa tradição, desde o período colonial, com mão de obra africana escravizada. No século XX permaneceu como importante campo de emprego de mulheres, marcado por grande informalidade". Atualmente, em relação aos aspectos legais, entrou em vigor a Proposta de Emenda Constitucional PEC das domésticas" - Lei complementar $\mathrm{n}^{\circ} 150$, de $1^{\circ}$ de junho de $2015^{7}$. Evidentemente esse marco legal traz um importante mecanismo de fiscalização do trabalho doméstico. No entanto, a natureza íntima e domiciliar do próprio trabalho o impede que seja monitorado. Sem dúvida, é uma correção histórica tardiamente reconhecida uma vez que, por décadas, legitimaram-se as desigualdades entre trabalhadores(as) domésticos(as) e outras categorias. No entanto, para este estudo é importante sinalizar que a regulamentação tem suas deficiências e que, muito embora se tenha uma garantia legal dos direitos trabalhistas, isso não implica em processos de redução das desigualdades sociais relacionadas às domésticas. E a soma dessas desigualdades reverbera em outras questões, tais como raça, classe, ser migrantes, etc. Assim, para melhor entender esse ganho legal, é preciso verificar com o tempo quais as reais modificações que foram contempladas.

Essa realidade gerou uma nova morfologia do trabalho doméstico que é a "diarização". Fraga (2010) chamou atenção para os motivos que levaram as empregadas domésticas a se "diarizar". Segundo ele:

O empobrecimento da classe média, que parece não conseguir reproduzir mais a mesma relação com o trabalhador doméstico que as gerações anteriores conseguiam; a diminuição do tamanho das famílias, com cada vez menos filhos, reduzindo a necessidade da contratação de serviços para todos os dias do mês; o crescimento do número de domicílios unipessoais, ou seja, de pessoas morando sozinhas; a eliminação dos custos que acompanham o vínculo empregatício; e o aumento da

\footnotetext{
${ }^{7}$ Dispõe sobre o contrato de trabalho doméstico; altera as Leis $\mathrm{n}^{\mathrm{0}}$ 8.212, de 24 de julho de 1991, no 8.213, de 24 de julho de 1991, e n⿳⺈ 11.196, de 21 de novembro de 2005; revoga o inciso I do art. $3^{\circ}$ da Lei $\mathrm{n}^{\mathrm{o}} 8.009$, de 29 de março de 1990, o art. 36 da Lei $\mathrm{n}^{\mathrm{o}} 8.213$, de 24 de julho de 1991, a Lei $\mathrm{n}^{\mathrm{0}} 5.859$, de 11 de dezembro de 1972, e o inciso VII do art. 12 da Lei no ${ }^{-} 9.250$, de 26 de dezembro 1995; e dá outras providências.
} 
participação feminina no mercado de trabalho, inclusive de mulheres casadas, com filhos e com menor poder aquisitivo, que veem na contratação de uma diarista a possibilidade de conseguirem articular trabalho e cuidados, delegando estes a um tipo de trabalhadora que caiba no orçamento familiar (FRAGA, 2010: 153).

Lugones (2008) traz boas reflexões para pensar que essas domésticas passam por distintas manifestações de discriminações que se intersectam entre raça, classe, gênero e sexualidade para entender a preocupante indiferença que os homens demonstram em relação à violência que sistematicamente infringem essa categoria; mulheres vítimas da colonialidade do poder e, inseparavelmente, da colonialidade de gênero.

Portanto, de acordo com Albuquerque (2005), as mulheres migrantes estão inseridas numa teia de relações de poder, em que as diferentes pertenças se conjugam de modo indissociável e contingente. Embora, sendo mulheres (patroas e domésticas, por exemplo), umas detêm mais poder do que outras. Essa assimetria de poder está embutida numa sociedade marcada pelas desigualdades em uma estrutura social ainda assentada em relações patriarcais, principalmente, quando se analisa do ponto de vista de Thurler (2011), as mulheres - pobres e não-brancas. A pauta dos processos migratórios secundarizou durante longo tempo dinâmicas importantes de opressão e dominação, de mudanças - tanto na apreensão das sociedades de partida, quanto nas sociedades receptoras. Grande parte dos estudos sobre migrações tem negligenciado as relações sociais de poder - entre elas, destacam-se as relações sociais de sexo -, presentes em uma e outra sociedade.

Logo, a mulher migrante está, com frequência, comprometida com sua origem. Não se pode esquecer que ela própria é também o reflexo da sua sociedade de origem e, por isso, está também marcada pela ideologia do gênero, ali, dominante. Ela própria possui um sentido de obrigação para corresponder a determinadas expectativas, o que repercute no nível das escolhas que for fazendo no seu percurso migratório (PEREIRA, 2006). Para essa mulher migrante, sua situação de vida, anônima, “invisível”, reflete no sentido de suas escolhas e revela aspectos das relações gênero que lhe são imbuídos ainda na 
sociedade de origem. Assim, elaboram estratégias para atenuar a sua sobrevivência em outro destino.

O processo migratório, na visão de Ramos (2014: 3), envolve "rupturas espaciais e temporais, transformações diversas, nomeadamente mudanças psicológicas, ambientais, biológicas, sociais, culturais, familiares, políticas, implicando a adaptação psicológica, cultural e social dos indivíduos e das famílias" e igualmente aculturação, que estabelecem um processo complexo, tendo como consequências no nível do desenvolvimento individual, familiar e socioprofissional, o que pode sobrecarregar a saúde física e psíquica. Para essas mulheres, a mobilidade e o deslocamento são vistos como perda de componentes subjetivos e objetivos de vida. Uma das principais queixas é a maternidade. Muitas migrantes veem-se vivendo longe de seus/suas filhos(as) e isto gera uma transferência da maternidade que implica na adaptação dos laços familiares.

Do ponto de vista de Assis (2007), a participação das mulheres nos processos migratórios ocorre articulada em uma complexa rede de apoio social. Embora as redes funcionem como mecanismos de integração e adaptação, Hellerman (2004) demonstra seu caráter ambíguo, ao apresentar duas razões para esta atitude: as redes sociais mais formais existem um nível elevado de controle, e a suspeição, que é o desrespeito e discriminação por parte dos seus compatriotas. Ambas as situações denotam o que Decimo (1998) chamou de "redes encapsuladas". A rede de relacionamentos é caracterizada por laços fortes e múltiplos que restringem cada indivíduo a um intercâmbio constante de dinheiro, serviços, informações e apoio moral. As protagonistas desse sistema de relações não veem a migração como uma ruptura com seu mundo de origem.

A incorporação das redes sociais nos fenômenos migratórios convergiu para análises em que a diferenciação sexual contribui para a permanência, persistência ou descontinuidades dos processos de mudança social e cultural. Como caracteriza Queiroz (2015), em sua pesquisa sobre a migração de mulheres guianeses para Boa Vista, em Roraima, estas mal se comunicavam em português, residiam nos locais de trabalho e não tinham 
assegurados direitos como férias, repouso semanal remunerado e salário mínimo. Ainda assim, preferiam a realidade do Brasil do que à imposta por seu país de origem. É através de contatos prévios, que vai desde conseguir o emprego, a moradia, informações e melhores condições de chegada, que o ato de migrar é estabelecido pelas redes sociais.

Mulheres são as principais responsáveis pela circulação de informação nas redes sociais e pela preservação dos laços com o local de origem. Esta foi a conclusão a que Assis (2007) chegou ao estudar famílias de migrantes de Criciúma/SC para os Estados Unidos. Os padrões de migração, as normas e a manutenção das obrigações familiares passam por uma rede de mulheres que capilarizam e socializam as informações do local de destino.

As redes sociais tornam-se um recurso precioso, pois se constituem em capital social, que segundo Assis (2003) auxilia pessoas com poucos recursos, pouca experiência profissional e baixo nível de escolaridade. Mais do que isso, as redes sociais são tecidas ao longo do processo migratório e não cessam com a chegada de migrantes ao seu destino. Há, portanto, relações de solidariedade, dádiva, reciprocidade, que essas migrantes constroem entre a origem e o destino, mas, também ao longo desse trecho e que vão auxiliar nos primeiros momentos da vida em um novo lugar.

O acionamento que essas mulheres realizam no processo migratório, antes e depois, da organização social, da confiança, das normas e sistemas, contribui para aumentar a eficiência do processo. Estes serão os conteúdos (capital social) circulantes presentes nas redes dessas mulheres. Para Bourdieu (1998) o capital social é um conjunto de relações de que o indivíduo ou grupo dispõe. E a forma como os sujeitos sociais o utilizam visa se posicionar nos espaços sociais em que estão inseridos.

Caracterização das duas redes migratórias: entre o contexto de vida e trabalho das trabalhadoras domésticas

Redes sociais nas migrações 
As redes na migração estão relacionadas com as interações interpessoais presentes no processo social migratório estando ligada com a sustentabilidade no destino. De acordo com Fazito (2002: 14) especifica-se "essa tipologia de rede social que tem como elementos fundamentais os fluxos populacionais trocados por regiões ou territórios que compõem um sistema social". Aqui, a incursão da experiência migratória é na rede de domésticas do bairro Village do Lago I - Montes Claros/MG .

De maneira geral as médias de idade, em 2017, era entre 40 e 44 anos. Além disso, essas mulheres tinham baixa escolaridade, sendo que, três possuíam o Ensino Fundamental Incompleto e uma o Ensino Médio, o equivalente a apenas cinco anos de estudos ou menos. Três se autodeclaram negras e uma branca. Apenas uma diz possuir carteira de trabalho assinada e as outras três, não. Quanto ao casamento, todas se disseram casadas e com filhos. "Quando eu falei para os meus pais que ia arrumar serviço de doméstica em Montes Claros, minha família me apoiou. A gente já sabia que tinha umas meninas indo. Eu fui também" (Marilda, 27 anos, 2013).

Em tela, esse depoimento de Marilda revela as dinâmicas presentes nas relações migratórias dessas mulheres. A família como um importante apoio social ao projeto migratório. As informações, confiança, cooperação que atuam como capital social oriundas das redes sociais das/nas migrações. Assim, qualquer que seja a influência, o que importa é perceber os alcances e os contextos de vida e trabalhos dessas mulheres.

$\mathrm{Na}$ rede do bairro Village do Lago I, de Montes Claros, percebeu-se que os laços de parentesco e amizades são preponderantes. As relações de parentesco, segundo Portugal (2014: 207), constituem “os laços mais ativos das redes sociais e do sistema de dádiva: é através deles que se estabelecem os

\footnotetext{
${ }^{8}$ A escolha desse local, chamou atenção devido aos estudos de Silveira (2016), que revelou a maior presença do sexo feminino, em função da composição familiar, "do lar", domésticas, diaristas e que acumulam a função de provedora da casa e responsável pelas questões burocrático-legais dos membros da família. Em relação à migração, encontramos moradoras com local de origem de várias cidades vizinhas a Montes Claros, mas, sobretudo, das zonas rurais, $42 \%$ dos(as) moradores(as) são originários(as) de municípios do Norte de Minas Gerais (SILVEIRA, 2016).
} 
fluxos mais intensos de apoio entreajuda; é no interior da rede de parentesco que se constroem os laços mais fortes".

Percebe-se como a migração repercute na vida e na família dessas mulheres. É no apoio emocional que se vivencia o afeto, a percepção do aconchego e do pertencer. O apoio familiar é um dos suportes mais proferidos nas falas dessas mulheres nas duas redes pesquisadas, "nesse sentido, as redes de suporte social representam os efetivos contatos provedores de ajudas, recursos e suportes dos migrantes, captando aqueles que lhes foram fundamentais e, assim, proporcionando uma discussão aprofundada sobre seu capital social" (CUNHA, 2014: 26).

A decisão de engajar-se no trabalho doméstico está ligada, em várias falas das nossas entrevistadas, aos constrangimentos materiais característicos da infância pobre, na zona rural do interior do estado. Ao chegarem à cidade, com a necessidade de desempenhar uma ocupação, acabam nos serviços vinculados aos cuidados (acompanhantes, babás, domésticas, etc.), o que, segundo elas, é mais fácil de conseguir, pois necessita apenas de uma indicação. Para essas mulheres, o trabalho doméstico, principalmente quando associado à moradia e à alimentação, é uma estratégia de sobrevivência conveniente logo que chegam à cidade grande, mas, na medida do possível, é provisória (NUNES, 1997).

Nasci em uma comunidade perto de Nova Esperança. Mudei para Nova Esperança com 13 anos. Minha avó e minha mãe trabalharam como domésticas. Minha irmã saiu antes com 12 anos, com minha tia, para Montes Claros. Foram indicadas pela minha mãe na casa da antiga patroa dela, que sabendo que fazemos o serviço direitinho, deu o serviço. Eles me pagavam pouco, meio salário mínimo, mas para mim era muito dinheiro. Até hoje [35 anos], trabalho como doméstica. Elas [patroas] estão sempre mudando de empregada (Magnólia, 35 anos, doméstica).

Mas aí eu não acho que você foi trabalhar como doméstica, você foi escravizada igual minha irmã. Chegava na casa, ela não dava conta de morar na casa sabe o que ela fazia? Voltava para trás. Ela fugia para casa da minha mãe, aí a mulher ia atrás e fazia minha irmã voltar para trás desse jeito. Aí porque sua filha vai morar aqui vai poder estudar e 
trabalhar, que estudar e trabalhar, que nada! É escravizada, moço! (Hortência, 41 anos, doméstica).

Aqui, notamos um imbricamento do cuidado e com circuito das “ajudas", que na visão de Guimarães e Vieira (2020: 11) "aparece como promotor de alternativas de cuidado (sob diferentes e novos tipos de atividades) entre aqueles que vivem em situação de pobreza extrema e sob escassa (ou pouco efetiva) proteção da política social”. Assim, as redes sociais nas migrações podem ser consideradas um dos principais recursos de que as domésticas dispõem no que diz respeito ao apoio recebido e percebido, seja na indicação para o trabalho ou na ajuda durante o processo migratório.

Leão (2017) evidencia aspectos criativos dos deslocamentos das domésticas migrantes “[...] que lançam mão para lidar com o distanciamento da família, com a dinâmica da cidade grande e a consequente necessidade da reorganização de suas vidas nesse espaço, com novas redes de solidariedade e sociabilidade" (LEÃO, 2017: 97).

Pelos relatos orais, exemplificam que o conteúdo das relações sociais que coadunam com atitudes de confiança, reciprocidade e cooperação proporcionam benefícios que, se não existissem, elas enfrentariam problemas em seus cotidianos, marcados pela dupla ou tripla jornada de trabalho, falta de recursos financeiros e suporte social, como na fala: "Graças a Deus, não teve isso, não, de ficar doente, mas se precisasse de dinheiro ou ajuda com os filhos, era essa prima que me ajudava (Marinalva, 40 anos, doméstica).

Portanto, percebe-se, entre as participantes da rede, que a confiança no grau de cooperação entre elas é maior. Esse fato se deve ao maior grau de coesão da rede do local de destino. Uma vez cumprida a etapa migratória e o tempo de migração, o acionamento da rede de apoio é mais rápido e de fácil acesso. As redes de reciprocidade, como afirma Guimarães e Vieira (2020: 20) "entre familiares e vizinhos, parecem ser tanto mais plurais e efetivas quanto mais ausente se mostra o Estado em suas políticas de cuidado e mais distante se faz o mercado, diante da escassez de rendimentos monetários". 
Nessa rede de domésticas as mulheres respondiam que o apoio para cuidar de filhos(as) crianças era fundamental nas relações com a formação da rede de apoio familiar, ou seja, as mulheres da família fornecem o elo da rede de cuidados. Nelas podem confiar.

Assim, o que evidenciam esses atributos é que a rede social dessas mulheres consiste numa rede de ajuda mútua feminina. Vasconcelos (2002) diz que a "feminização" das redes deve ser entendida pela preponderância de apoios prestados pelas mulheres. Assim, assume-se o malabarismo em conciliar trabalho-cuidado-família apoiando-se nas redes sociais, como forma de dádiva e reciprocidade, aprofundando o processo de "hipersegmentação sexual do trabalho" (HIRATA, 2007), com mulheres transferindo cuidados para outras.

Assis e Siqueira (2009) dizem que, no processo migratório, com o passar dos tempos, enquanto as redes sociais dos homens expandem-se, as redes das mulheres retraem-se. Isto influencia nas oportunidades de encontrarem novas redes e libertarem-se do gueto do trabalho doméstico e do eterno refúgio a que estão propensas ao migrarem para as casas das patroas.

As mulheres migrantes do norte de Minas Gerais que foram "rumo à cidade" encontraram novos desafios, muitas relatam mais trabalho, mais afazeres nas "casas dos outros", às vezes, uma tripla jornada de trabalhos, pois, ao morarem nas casas, trabalham à noite e aos finais de semana. São dilemas bem evidentes nesse momento, pois a Lei da Proposta de Emenda à Constituição (PEC) das domésticas, que foi uma conquista dessas trabalhadoras, não tem sido referência para alcançar os postos de trabalho, como aponta Guedes e Monçores (2019) ainda é marcado pela precariedade, exercido por mulheres pretas e pardas, apresentam baixo nível de remuneração e de proteção social e alta carga horária de trabalho remunerado, somada a extensas jornadas.

$\mathrm{Na}$ rede de domésticas do bairro Village do Lago I - Montes Claros/MG, verifica-se que a permanência mais prolongada gira em torno das redes de suporte social constituídas no bairro escolhido. Pelos relatos, são experiências migratórias, desvelando os elementos que envolvem as decisões de 
ficar, que estão vinculadas ao universo do trabalho, do espaço (bairro), das aspirações de cada uma e da rede de suporte social (redes pessoais - de ajuda mútua, dádiva e reciprocidade), funcionando como mecanismo adaptativo, subordinando e condicionando as que vêm de fora no seu desenvolvimento no lugar. São redes de estratégias de sobrevivência e de sustentabilidade (redes na migração).

Redes sociais das migrações

As redes $d a$ migração vinculam-se aos recursos disponíveis para agir em contextos migratórios, como ajuda, capital social e a cultura migratória necessários para o deslocamento. "Salienta-se o conteúdo e diversas dimensões das relações sociais que participam no processo social da migração" (FAZITO, 2002: 14). Assim, tem-se a rede de domésticas dos municípios mineiros de Mirabela e São Francisco para a capital de Minas Gerais, Belo Horizonte, e São Paulo (capital).

As participantes dessa rede, em 2017, declararam idades compreendidas entre 43 a 58 anos. Em relação ao nível de escolaridade, três possuíam Ensino Fundamental Incompleto e uma o Ensino Médio Incompleto equivalente há menos de oito anos de estudos. Todas se autodeclararam negras. Todas confirmam não ter carteira de trabalho assinada. Três possuem experiência matrimonial com filhos e uma se diz solteira. Os dados coletados sobre as trajetórias de vida das trabalhadoras domésticas confirmam que as quatro entrevistadas que trabalham nos grandes centros urbanos são migrantes, provenientes do norte de Minas Gerais, e de origem rural.

O trabalho doméstico constitui fonte empregadora da maioria das mulheres migrantes. A migração campo-cidade, no Brasil, constitui-se em uma das formas de provisão do trabalho doméstico. Percebe-se que a primeira mulher que migra inaugura a entrada de outras mulheres neste nicho de mercado de trabalho. A partir da demanda das "amigas da patroa", passa-se a recrutar e alocar mulheres de suas comunidades rurais. E, assim, o ciclo das 
redes de relações sociais para o trabalho doméstico efetivam-se e mantem-se: "É porque ela estava junto com a menina que me levou, porque meus pais só deixaram eu ir porque ela estava indo e ia me entregar nas mãos da patroa" (Marinalva, 40 anos, doméstica).

A interpretação dessa origem comum das domésticas pode ser vista como uma prática cultural aliada à "cultura doméstica" e à "cultura migratória" das famílias pobres da região Norte de Minas Gerais, configurando-se, também, como uma tática de sobrevivência articulada às construções de gênero dos grupos familiares desprovidos da zona rural e das redes sociais. A fala de Marinalva se vincula ao preconizado por Fazito (2002: 6), de que, "as redes sociais são aquelas que relacionam indivíduos em suas redes pessoais cotidianas, que se consolidam empiricamente nas redes de parentesco e amizade dentro da comunidade".

A mobilidade espacial na vida de trabalhadoras domésticas migrantes, oriundas de comunidades rurais e suas relações pessoais, servem para dar continuação ao processo migratório no sentido de conseguir informação, escolher o destino e inserir-se no mercado de trabalho da sociedade receptora. Vejamos:

Nós, as meninas da minha mãe sempre vamos muito cedo para São Paulo. Ela tinha uns dezesseis anos, eu tinha uns onze. Nós sempre vamos muito cedo para a cidade grande trabalhar de doméstica e depois nós voltamos, no caso elas ficaram por lá mesmo (Denise, 58 anos, doméstica).

Esse relato oral coaduna com as questões geracionais que estão presentes nas relações do trabalho doméstico. Leão (2017) chama atenção para um aspecto relevante que é a forte presença das relações familiares, especialmente de irmãs, filhas que, sendo mais velha do que elas e vivendo há mais tempo em São Paulo, lhe orientava sobre como lidar com as situações adversas do trabalho. A maioria das mães das trabalhadoras domésticas entrevistadas disseram que já prestaram serviços domésticos, em alguma época da vida, ou ainda continuam a realizá-los, assim como revelou-se também que ele está presente entre as gerações das mulheres de uma mesma família. 
Logo, quando se analisa do ponto de vista da sujeição a que estão submetidas estas mulheres, elas estão muito sós e, por esta razão, encontram-se numa situação extremamente vulnerável. Desde o desemprego e a falta de oportunidades, a pobreza, violências familiares, necessidade de sustentar a família, melhores condições de educação para os filhos, existência de redes sociais e familiares, dentre outras situações, estão nas motivações que levam as mulheres a migrar, buscando dar respostas às necessidades básicas do cotidiano, colocando-as sempre entre dois mundos, aquele onde está agora e aquele onde estão os que ficaram.

Oh, eu acho que foi assim, eu não sei te explicar quem foi, mas a maioria assim. Uma foi primeiro, aí tipo assim, aí como tem família aqui, uma passa para a outra é melhor e aí por diante. São desse jeito e vai indo, vai indo, vai indo. E igual eu te falei, minha mãe, o fato dela ter ido para São Paulo e depois foi para Belo Horizonte e nisso por ela ser a única que morava lá, aí depois as irmãs dela mesmo foram para lá, moram lá. E foi assim através de uma que acaba levando a outra, é melhor assim e assim por diante vai (Amélia, 40 anos, doméstica).

Foi com minha filha que foi. Mas é por isso que eu vou falar com você que tem pessoa lá que sabe o que fala: ah, se fulana vim, eu consigo um serviço para ela. Então, através disso, minha filha mesmo foi, foi assim através de outra que trabalhava lá e levou ela, encaixou ela. Então, é por isso que eu falo que uma vai passando para as outras (Cecília, 50 anos, doméstica).

Nessas falas destacam-se o que na visão de Santos (2015: 5) reflete que na "cidade além de se constituírem em intermediárias na migração de outros membros do grupo familiar, essas mulheres podiam ajudar suas famílias em tempos de necessidade, a função de membro assalariado que socorre a unidade familiar".

Assim, percebe-se a compreensão do trabalho doméstico e a migração interna de mulheres rurais, pobres, com os pressupostos segundo Monticelli (2017: 5): "servilistas, que muitas vezes se conectam com práticas discriminatórias e desiguais. São justamente esses discursos, práticas, lógicas, símbolos e representações que fazem parte da "cultura doméstica". A "cultura doméstica" é intrinsecamente formada nas relações de poder familiares, da 
divisão sexual do trabalho, nos espaços, lugares e constitui importante posição que diferenciam e mantem hierarquias, no Brasil, muito comum à cooptação de jovens do meio rural para se empregar em casas de família nas cidades com várias justificativas: "estudar", "comprar suas coisinhas", "apadrinhar", "fazer companhia", "ajudar a olhar as crianças”, etc. Aqui, o universo das narrativas trazem elementos que coadunam com a servilidade e a imigração.

Quando a relação pessoal entre patroa-doméstica se confunde com paternalismo com relações de trabalho que culminam em garantia de direitos patroas e trabalhadoras domésticas, em geral, participam de uma relação de identidade mediada pela lógica de servir aos outros como algo natural, embora essa relação trabalhista passe por uma contradição de classe e outra de identidade-gênero que é estabelecida entre as mulheres, como afirma Lisboa (2006).

Pesquisador: Você trabalhou lá em quantas casas?

Carmélia: Eu trabalhei... Oh, minha filha, eu trabalhei em várias casas lá.

Pesquisador: De empregada doméstica? Muitas mulheres vão trabalhar de domésticas lá?

Carmélia: É. Várias... Várias.

Pesquisador: Como que vocês ficam sabendo desses empregos?

Carmélia: Não. Informação dos outros que iam passando. Uma ia passando para outra e indicando como que era o serviço. Aí, eu conseguia pegar o serviço (Carmélia, 43 anos, doméstica).

Assim sendo, deve-se destacar a importância das redes, para Leão (2017: 97) “[...] que vão sendo formadas, seja o contato com um familiar distante, com conhecidos migrantes ou ainda com vizinhos, que acabam por se tornar personagens importantes na vida dessas mulheres".

As redes promovem a inserção no mercado laboral como relata a passagem descrita acima, a adaptação na sociedade receptora e na manutenção dos laços familiares e culturais com a região de origem/destino e igualmente uma guetização dos empregos femininos. De fato, as redes sociais abarcam uma rede de suporte social derivados, mas, que, no entanto, são considerados como 
um banco de favores que as migrantes possuem e disponibilizam, como estoque de recursos, ajudas, informações e suportes na chegada (CUNHA, 2014).

\begin{abstract}
Outra capital não, só para Belo Horizonte! Não estou falando com você. Eu fui para outra capital, não gostei, eu já fui uma vez para Brasília a passeio, não gostei, muitos anos, muitos anos atrás quando meu marido ainda era vivo, eu fui passear lá também, aquilo tudo já mudou já. Mais eu fui lá uma vez mais ele e não gostei, sabe? O único lugarzinho que eu gostei, acho que é porque eu fiquei muito tempo, entendeu, foi em Belo Horizonte. São Paulo mesmo Deus me livre, não gostei. É mais cansativo, principalmente Belo Horizonte, por que, em São Paulo, as faxinas de lá chega a ser melhor do que em BH. Já Belo Horizonte a faxina de lá é mais dura que em São Paulo, eu gostei das faxinas em São Paulo. A faxina em São Paulo é mais ou menos assim ... A casa não precisa jogar água, lavar o azulejo de cozinha também, não! Não precisa de jogar água, lá tem as coisas para limpar e já em BH não você tinha que jogar água (Carmélia, 43 anos, doméstica).
\end{abstract}

Tomamos a informação e a assistência prestada a migrante como recurso do capital social. Assim, quanto mais ela migrar, maiores serão seus recursos de informações, diversificados e acessíveis. Carmélia utiliza desses retornos na origem para trazer novidades, informação e, também, para descansar e momentos de lazer, já que o trabalho em São Paulo requer muitas horas de trabalho.

O sentimento de pertecimento de grupo pela fala de Carmélia se dá em função dos vínculos que ela estabeleceu no lugar em que mais tempo morou. Na visão de Bourdieu (2007: 65): “essas ligações são irredutíveis às relações objetivas de proximidade no espaço físico (geográfico) ou no espaço econômico e social, porque são fundadas em trocas materiais e simbólicas que supõe re-conhecimento". O capital social apresenta-se, portanto, como um de seus domínios certa maleabilidade, que se expressa na probabilidade de conversão de uma forma para outra. No caso de Carmélia, sua adaptação em outras cidades pode passar do sentimento de não pertencimento para o pertencimento a depender das redes que formar

Trata-se de um capital social que propicia uma rede de contatos e informações sobre as vagas disponíveis, bem como de recomendações para 
onde, quando e como se obter um emprego. Esse capital social é o resultado de uma estratégia fundamentada na relação entre a indicada, a indicadora e o/a empregador(a). Nessa tríade, os interesses, apesar de serem diferenciados, são baseados numa reciprocidade de favores que reanima os códigos de confiança e funcionalidade dessa relação (SERTÓRIO; SANTOS, 2010).

Pelos relatos orais das participantes, a função de regulação social dessa rede social se fez presente de forma horizontal, não como forma de controle social, mas como auto-organização social e assimilação, são frutos dos processos de adaptação da migrante nas cidades (São Paulo/ SP e Belo Horizonte/ MG). Na visão de Bourdieu (1990), é uma "estratégia como orientação da prática, que não é nem consciente, nem calculada, nem mecanicamente determinada", mas que é produto do senso coletivo. E os patrões foram peças fundamentais para garantir o elo entre a experiência migratória da doméstica com o mundo exterior (as cidades). Dessa forma, ela estabelece negociação no convívio cotidiano, coexistindo com as diferenças. As redes pesquisadas possuem regulação social positiva para cimentar o processo migratório dessas mulheres, embora as redes sejam fechadas, restritas ao universo familiar, o que as tornas refugiadas em poucos círculos sociais.

A rede de domésticas das zonas rurais de dois munícipios vizinhos a Montes Claros/MG, Mirabela e São Francisco, revelou-se como uma migração "permanente e temporária"9. As práticas migratórias em um contexto de vida e trabalho demonstram que o trabalho doméstico de diarista é a principal ocupação e com uma frequente rotatividade. As migrações de retorno permeiam muitos dos relatos, por algum equívoco de avaliação quanto às casas de famílias, das patroas, das relações de trabalho no local de destino (Belo Horizonte, São Paulo), o que resulta em frustração no que tange às expectativas. Trata-se de uma rede $d a$ migração na medida em que a rede de apoio social migratória se reveste da presença de uma grande "força" dos lugares de origem

\footnotetext{
${ }^{9}$ Utilizo os termos "permanente e temporária" para fazer um reparo ao leitor para elementos de expulsão e atração em jogo no deslocamento das mulheres dessa rede em que há uma constante migração de retorno.
} 
que conectam aos lugares de destino, evidenciando que o processo social da migração é cumulativo, dinâmico e estruturado pelo capital social.

\section{Para não concluir...}

Este estudo, ao discutir as relações migratórias com enfoque nas redes sociais, considera a imigração estudada constituída por mulheres que acolhem outras mulheres e constroem os diversos conteúdos que auxiliam a compreender o processo migratório enquanto dinâmico, estratificado e desigual. Redes de reciprocidade em tempos áridos e individualista. Redes que perpassam sentidos e sentimentos, permeiam perdas, tristezas e enfrentamentos cotidianos. É dessa maneira que recorreu-se à História Oral para entender como acontece a formação, manutenção e os conteúdos das redes sociais revelados pelas estratégias de reprodução da vida dessas trabalhadoras domésticas migrantes, que estão calcadas em redes sociais das/nas migrações.

Pelos relatos orais das trabalhadoras domésticas migrantes foi possível caracterizar duas tipologias de redes sociais que dão suporte à migração e constituem-se como estratégias em um contexto de vida e trabalho. As redes na migração acontecem no pertencimento, no lugar de origem, na constituição da viagem para o lugar de destino (bairro) em grupo ou na solidariedade do encontro no lugar de destino, na expectativa da "melhoria de vida" através do trabalho doméstico. O compartilhamento de dificuldades e apoio, no enfrentamento das mesmas, fortalece as redes e facilita sua ampliação.

As redes $d a$ migração apontaram cidade de São Paulo (capital) como um destino das domésticas, o que permitem atentar à espacialidade na busca por trabalho. Verificou-se que há uma escala de preferência, baseada na experiência do binômio da migração ("fracasso e sucesso"), pelos destinos migratórios. Constatou-se também o papel intermediário da capital de Minas Gerais, Belo Horizonte. A posição de intermediação nesse sistema migratório é em função do parentesco, da conterraneidade e do pertencimento. A maioria das 
famílias tem a migração para a capital mineira como a primeira experiência de deslocamento, em função de serem conhecidos(as) ou da mesma comunidade e, finalmente, a proximidade com a cultura e a origem. Assim, evidencia-se o parentesco como condição primordial para a compreensão das redes sociais.

Diante de um panorama geral das mudanças nas relações de trabalho com o desenvolvimento de uma economia globalizada, a feminização da migração destaca-se na atual fase em que o capitalismo neoliberal assume para si o contingente de mulheres para garantir a reprodução da sua força de trabalho. Revelam-se, tanto no plano material, quanto no simbólico, a reprodução das desigualdades e a exploração do trabalho da mulher.

Assim, o trabalho doméstico no Brasil permanece sob a roupagem de problema de classe, de gênero e de raça, aspectos até hoje associados e indissociáveis. Pois, vincula-o desde o início, no cruzamento e herança do trabalho escravo, trabalho realizado "por negras", trabalho "feminino", trabalho "migrante", trabalho "geracional", trabalho "sujo, degradante e perigoso". Logo, as articulações entre essas esferas posicionam as migrantes em nível inferior, colaborando para sua inserção marginal no mercado de trabalho.

A inserção de homens e mulheres migrantes no mercado de trabalho evidencia questões do tipo como se rearticulam as relações de gênero, a tônica da busca de melhores condições de vida para si, mesmo com o advento da Proposta de Emenda à Constituição - PEC das Domésticas. A contratação de uma trabalhadora doméstica passou a ser uma forma de resolver as tensões de um contrato de gênero em crise sem alterar esse contrato. Previsões na visão de Pinheiro, Fontoura e Pedrosa (2012), é que as pesquisas apontam para a inexistência de uma reposição geracional desta categoria, o que significa que a ocupação tem sido sustentada por um estoque de trabalhadoras que tende a se reduzir cada vez mais, seja pelo próprio aspecto demográfico, seja porque conseguem aposentar-se e retirar-se do mercado. Assim, é possível pensar que, dado o processo de envelhecimento populacional e o surgimento de novas possibilidades ocupacionais para as jovens trabalhadoras, o trabalho doméstico - da forma como conhecemos hoje - tende a se reduzir drasticamente, e a uma 
nova morfologia do trabalho doméstico, que é a "diarização" (FRAGA, 2010) sem proteção social.

Constatamos que a interação em rede, do ponto de vista das relações históricas efetivadas no cotidiano, foi direcionada pelas dinâmicas das redes, dos locais de origem. A construção de novas redes nos centros urbanos, inclusive, pela própria dinâmica do capital migratório e da "cultura do migrar", tenta reproduzir nos locais de destino o sentimento de pertencer a um grupo e a um lugar. Pertencimento que compõe junto com outras mulheres que fazem o mesmo percurso, com base na confiabilidade e na reciprocidade, auxiliando na manutenção da rede.

Temos aqui contribuições sobre as relações migratórias que se perpetuam anos após anos, afinadas com as desiguais relações de gênero que definem a condição e o lugar social que as mulheres migrantes, trabalhadoras domésticas, vão assumir na força de trabalho. Portanto, a inflexão entre migração e gênero indica que há grandes chances de estarmos sempre retomando e analisando os desdobramentos da migração rural feminina para os grandes centros urbanos no Brasil. Ainda pertinentes ao debate, algumas questões mereceriam ser tratadas de maneira específica, já que se apresentam como desdobramentos para futuras reflexões: uma é a relação famíliaparentesco como matriz das redes sociais. Outra diz respeito a noção de capital social de migração para além dos aspectos econômicos, culturais, humanos, mas, sobretudo, simbólicos para migrantes, ex-migrantes e futuras migrantes, pois se reveste de um recurso que é produzido, distribuído, consumido e investido.

\section{Referências}

ALBUQUERQUE, Rosana. Um olhar sobre a participação das mulheres em associações de imigrantes. In: SOS RACISMO (ed.). Imigração e etnicidade. Vivência e trajectórias de Mulheres em Porugal, Lisboa, SOS Racismo, 2005. p. 105-118.

ASSIS, Gláucia Oliveira. "De Criciúma para o mundo" - Os novos fluxos da população brasileira: gênero e rearranjos familiares. In: MARTES, Ana Cristina 
Braga; FLEISCHER, Soraya. (Orgs.). Fronteiras Cruzadas: etnicidade, gênero e redes sociais. São Paulo: Editora Paz e Terra, 2003. p. 199-230.

Mulheres migrantes no passado e no presente: gênero, redes sociais e migração internacional. Revista Estudos Feministas, Florianópolis, n. 15, v. 3, p. 745- 772, set./ dez. 2007.

; SIQUEIRA, Sueli. Mulheres emigrantes e a configuração de redes sociais: construindo conexões entre o Brasil e os Estados Unidos. REMHU, Brasília, v. 16, p. 25-46, jan./ dez. 2009.

ÁVILA. Maria Betânia. O tempo do trabalho doméstico remunerado: entre cidadania e servidão. In: ABREU, Alice Rangel de Paiva; HIRATA, Helena; LOMBARDI, Maria Rosa. Gênero e trabalho no Brasil e na França: perspectivas interseccionais. São Paulo: Boitempo, 2016.

BAPTISTA, Patrícia Gonçalves. Imigração e trabalho doméstico: o caso Português. 180 f. 2011. Dissertação (Mestrado em Desenvolvimento e Cooperação Internacional) - Programa de Pós-graduação em Desenvolvimento e Cooperação Internacional, Instituto Superior de Economia e Gestão, Universidade Técnica de Lisboa, 2011.

BOLETIM PAD-MG. Mercado de trabalho e Gênero, ano 1, $\mathrm{n}^{\circ}$. 1, maio 2011. Belo Horizonte, Fundação João Pinheiro, Centro de Estatística e Informações, 2011.

BOURDIEU, Pierre. O capital social - notas provisórias. In: NOGUEIRA, Maria Alice; CATANI, Afrânio. (orgs.). Escritos de educação. 9. ed. Petrópolis: Vozes, 2007.

. Coisas ditas. Brasiliense: São Paulo, 1990.

O poder simbólico. Rio de Janeiro: Bertrand Brasil, 1998.

CATARINO, Christine, OSO, Laura. "La immigración femenina em Madrid y Lisboa: hacia uma etnización del servicio doméstico y de las empresas de limpeza", Papers, Bellaterra, v. 60, p. 183-207, 2000.

CHANEY, Elsa; GARCIA CASTRO, Mary. Introduction: A new Field for research and action. In: CHANEY, Elsa; GARCIA CASTRO, Mary. (Orgs.). Muchachas no more: household workers in Latin America and the caribean. Philadelphia: Temple University Press, 1989. Cap. 3: Empregadas e patroas no Rio de Janeiro: percepções sobre a casa e a rua em 1870.

COSTA, Francilene Soares de Medeiros. A diarização do trabalho doméstico remunerado no Brasil e os dilemas atuais da (des)proteção social. 208 f. 2017. 
Tese (Doutorado em Geografia) - Programa de Pós-Graduação em Geografia, Universidade Estadual Paulista, Presidente Prudente, 2017.

CUNHA, Tiago Augusto da. Conte Comigo. A migração abrindo portas. Migração Interna, Redes de Suporte e Vulnerabilidade Social na Região Metropolitana de Campinas. 237 f. 2014. Tese (Doutorado em Demografia) Programa de Pós-graduação em Demografia, Universidade Estadual de Campinas, 2014.

DIEESE. Departamento Intersindical de Estatística e Estudos Socioeconômicos. Trabalhadoras domésticas na Região Metropolitana de São Paulo. 2019. Disponível

em: https://www.dieese.org.br/analiseped/2019/2019empreDomSAO.pdf. Acesso em: 28 mai. 2019.

DECIMO, Francesca. Living the city the urban integration of Somali women in Naples. In: FERREIRA, V.; TAVARES, T.; PORTUGAL, S. (Orgs.). Shifiting bonds, shifting bounds: women, mobility and citizenship in Europe. Oeiras: Celta Editora, 1998. p. 253-259.

EHRENREICH, Barbara, \& HOCHSCHILD, Arlie Russel. R. Global woman: nannies, maids and sex workers in the new economy. London: Granta Books, 2003.

FAZITO, Dimitri. A Análise de Redes Sociais (ARS) e a Migração: mito e realidade. In: XIII ENCONTRO DA ASSOCIAÇÃO BRASILEIRA DE ESTUDOS POPULACIONAIS, 2002, Ouro Preto. Anais ... Ouro Preto: ABEP, 2002.

FÉLIX, José Fontes. O trabalho doméstico de adolescentes: naturalização da exclusão e submissão. 111 f. 2010. Dissertação (Mestrado em Sociologia) Universidade Federal do Rio Grande do Norte, Natal, 2010.

FERREIRA, Jorgetânia da Silva. Trabalho em domicílio: trabalho em domicílio: quotidiano de trabalhadoras domésticas quotidiano de trabalhadoras domésticas e patroas. Caderno Espaço Feminino, Uberlândia, v. 23, n. 1/ 2, p. 339-360, jun./ dez. 2010.

FONSECA, Gildette Soares. Espacialidade das migrações temporárias de mirabelenses - implicações na territorialidade local. 148 f. 2009. Dissertação (Mestrado em Geografia) - Programa de Pós-graduação em Geografia, Pontifícia Universidade Católica de São Paulo, São Paulo, 2009.

Migrações da mesorregião Norte de Minas/MG: análises do Censo Demográfico de 2010. 310 f. 2015. Tese (Doutorado em Geografia Tratamento da Informação Espacial) - Pontifícia Universidade Católica de Minas Gerais, Belo Horizonte, 2015. 
FRAGA, Alexandre Barbosa. De empregada a diarista: as novas configurações do trabalho doméstico remunerado. 173 f. 2010. Dissertação (Mestrado em Sociologia e Antropologia) - Universidade Federal do Rio de Janeiro, Rio de Janeiro, 2010.

GONZALEZ, Ana Elizabeth León; PARDO, Catalina Revollo. Relações e redes do cuidado no contexto migratório de mulheres latino-americanas. In: SEMINÁRIO INTERNACIONAL FAZENDO GÊNERO, 11, Florianópolis. Anais ... Florianópolis, 2017.

GUEDES, André Dumans. Abrir no Mundo, Rasgando o Trecho: Mobilidade Popular, Família e Grandes Projetos de Desenvolvimento. Cadernos de Campo, São Paulo, v. 21, n. 21, p. 137-152, jan./ dez. 2012.

GUEDES, Graciele Pereira; MONÇORES, Elisa. Empregadas domésticas e cuidadoras profissionais: compartilhando as fronteiras da precariedade. Revista Brasileira de Estudos populacionais, São Paulo, v. 36, p. 1-24, 2019.

GUIMARAES, Nadya Araújo; VIEIRA, Priscila Pereira Faria. As "ajudas": o cuidado que não diz seu nome. Estudos Avançados, São Paulo, v. 34, n. 98, p. 7-24, abr. 2020.

HAGAN, Jacqueline Maria. "Social Networks, Gender and Immigrant Incorporation: Resources and Constraints", American Sociological Review, Washington, v. 63, n. 1, p. 55-67, 1998.

HELLERMANN, Christiane. Uma relação difícil? Mulheres imigrantes da Europa de Leste e redes sociais. Actas dos ateliers do V Congresso Português de Sociologia, $2004 . \quad$ Disponível em: http://www.aps.pt/cms/docs_prv/docs/DPR4628e0fa38281_1.pdf. Acesso em: 5 jan. 2016.

HERRERA, Gioconda. Género y migración internacional en la experiencia latinoamericana. De la visibilización del campo a una presencia selectiva. Política y sociedad, Madrid, v. 49, n. 1, p. 35-46, 2012.

HIRATA, Helena. Entrevista. Trabalho, Educação e Saúde, Rio de Janeiro, v. 4, n. 1, mar. 2006.

KERGOAT, Danièle. Novas configurações da divisão sexual do trabalho. Cadernos de Pesquisa, São Paulo, v. 37, n. 132, p. 595-609, set./ dez. 2007.

IBGE. Instituto Brasileiro de Geografia e Estatística. Censo Demográfico de 2010. Rio de Janeiro: IBGE, 2010. 
Pesquisa Nacional por Amostra de Domicílios (PNAD) 2014. Disponível em: http://www.ibge.gov.br. Acesso em: 25 abr. 2019.

KOFES, Suely. Mulher, mulheres: Diferença e Identidade nas armadilhas da igualdade e desigualdade - Interação e relação entre patroas e empregadas domésticas. 450 f. 1990. Tese (Doutorado em Sociologia) - Faculdade de Filosofia, Letras e Ciências Humanas, Universidade de São Paulo, São Paulo, 1990.

KOFMAN, Eleonore; RAGHURAM, Parvati. Women, Migration, and Care: Explorations of Diversity and Dynamism in the Global South. Social Politics, Oxford, UK, v. 19, n. 3, p. 2-26, sept. 2012.

LEÃO, Leilyane Souza. Entre a Bahia e São Paulo: narrativa feminina sobre migração e trabalho doméstico. Revista da ABET, João Pessoa, v. 16, n. 2, p. 90-99, jul./dez. de 2017.

LISBOA, Teresa Kleba. Fluxos migratórios de mulheres para o trabalho reprodutivo: a globalização da assistência. Revista de Estudos Feministas, Florianópolis, v. 15, n. 3, p. 805-821, set./ dez. 2006.

Fluxos migratórios de mulheres para o trabalho reprodutivo: a globalização da assistência. Revista de Estudos Feministas, Florianópolis, v. 15, n. 3, p. 805-821, 2007.

LUGONES, María. Colonialidad y Género. Tabula Rasa, Bogotá, v. 9, p. 73$101,2008$.

MONTICELLI, Thays. "Administrando o lar": a percepção de uma "cultura doméstica" e os desafios do trabalho doméstico remunerado. In: SEMINÁRIO INTERNACIONAL FAZENDO GÊNERO, 11, Florianópolis. Anais... Florianópolis, 2017.

MORI, Natalia; BERNARDINO-COSTA, Joaze; FLEISCHER, Soraya. Introdução. In: MORI, Natalia; FLEISCHER, Soraya; FIGUEIREDO, Angela; BERNARDINO-COSTA, Joaze; CRUZ, Tânia. (Orgs.), Tensões $e$ experiências: um retrato das trabalhadoras domésticas de Brasília e Salvador. Brasília: CFEMEA, MDG3 Fund., p. 15-28.

MOTTA, Alda Brito da. Visão de mundo da empregada doméstica: um estudo de caso. 1977. Dissertação (Mestrado em Ciências Humanas) - Pós-graduação em Ciências Humanas, Universidade Federal da Bahia, 1977.

NETO, Maria Inácia D’Ávila; NAZARETH, Juliana. Redes sociais na experiência migratória de mulheres nordestinas. 2012. Disponível em: http://www.abrapso.org.br/siteprincipal/images/Anais_XVENABRAPSO/315. 
\%20redes $\% 20$ sociais $\% 20$ na\%20experi\%CAncia\%20migrat $\%$ D3ria\%20de $\% 20$ mulheres\%20nordestinas.pdf. Acesso em: 23 out. 2012.

NUNES, Christiane Girard Ferreira. Identidade e cultura: reflexões sobre uma categoria sócio profissional. In: NUNES, Brasilmar Ferreira et al. (Orgs.). Brasília: a construção do cotidiano. Brasília: Paralelo 15, 1997. p.179-206.

OIT. Organização Internacional do Trabalho. Global estimates on migrant workers. 2016. Disponível em: http://ilo.org/global/topics/labourmigration/publications/WCMS_436343/lang--en/index.htm/ .Acesso em: 12 dez. 2018.

PAULA, Andrea Maria Narciso Rocha de. Integração dos migrantes rurais no mercado de trabalho em Montes Claros, norte de Minas Gerais: "a esperança de melhoria de vida". 151 f. 2003. Dissertação (Mestrado em Geografia) Universidade Federal de Uberlândia, Uberlândia, 2003.

TRAVESSIAS... Movimentos migratórios em comunidades rurais no Sertão do norte de Minas Gerais. 350 f. 2009. Tese (Doutorado em Geografia) Universidade Federal de Uberlândia, Uberlândia, 2009.

PEREIRA, Elisabete Maria Magalhães. Mulheres migrantes de São Tomé e Príncipe em Portugal - Um estudo de caso no Bairro Vale de Chícharos. 217 f. 2006. Dissertação (Mestrado em Relações Interculturais) - Programa de Pósgraduação em Relações Interculturais, Universidade Aberta, Lisboa, 2006.

PEREIRA, Laurindo Mékie. Em nome da região, a serviço do capital: o regionalismo político norte-mineiro. 242 f. 2007. Tese (Doutorado em História Econômica) - Programa de Pós-Graduação em História Econômica, Universidade de São Paulo, São Paulo, 2007.

PINHEIRO, Luana; FONTOURA, Natalia; PEDROSA, Cláudia. Situação das trabalhadoras domésticas no país. IN: CASTRO, Jorge Abrahão de; ARAÚJO, Herton Ellery (Orgs.) Situação das trabalhadoras domésticas no país. Situação social brasileira: monitoramento das condições de vida 2. Brasília: IPEA, 2012.

PORTELLI, Alessandro. Ensaios de História Oral. São Paulo: Letra e Voz, 2012.

PORTUGAL, Sílvia. Famílias e Redes Sociais ligações fortes na produção de bem-estar. Coimbra: Edições Almedina, 2014.

QUEIROZ, Claudia de Oliveira Carvalho. A feminização da migração: trabalho doméstico, emancipação e redes sociais na fronteira Brasil-Guiana. 88 f. 2015. Dissertação (Programa de Pós-graduação em Relações Internacionais) - Centro 
de Ciências Biológicas e Sociais Aplicadas, Universidade Estadual da Paraíba, João Pessoa, 2015.

RAMOS, Natália. Gênero, identidade e maternidade na diáspora. In: SIMA, Rosa Neves (org.). A vez e a voz da mulher: relações e migrações. In: VI CONGRESSO INTERNACIONAL, 6, 2014, Ponta Delgada, Portugal. Anais... Ponta Delgada, Portugal, 2014.

SANTOS, Rosana de Jesus dos. Corpos domesticados: a violência de gênero no cotidiano das domésticas em Montes Claros-1959 a 1983. 152 f. 2009. Dissertação (Mestrado em História) - Programa de Pós-graduação em História, Universidade Federal de Uberlândia, Uberlândia, 2009.

Trabalho doméstico remunerado e migração feminina: as construções de gênero na cultura dos lavradores do norte de Minas Gerais. Fato \& Versões - Revista de História, Coxim, v. 7, n. 13, p. 1-16, outubro de 2015.

SAYAD, Abdelmalek. Imigração ou os Paradoxos da Alteridade. São Paulo: EDUSP, 1998.

SERTÓRIO, Lidiane Bruno; SANTOS, Miriam de Oliveira. O. Relações entre trabalho, educação, gênero e migração. 2010. Disponível em: http://www.estudosdotrabalho.org/anais-vii-7-seminario-trabalho-ret-

2010/Lidiane_Bruno_Sertorio_e_Miriam_de_Oliveira_Santos_relacoes_entre_t rabalho_educacao_genero_e_migracao.pdf. Acesso em: 23 mar. 2012.

SILVEIRA, Mário Sérgio Costa da. Análise da Qualidade de Vida dos Bairros Clarice Ataíde, Novo Horizonte e Village do Lago I e II na Cidade de Montes Claros tendo como base o Índice de Vulnerabilidade das Famílias (IVF). $216 \mathrm{f}$. 2016. Dissertação (Mestrado em Sociologia Política) - Universidade Federal de Santa Catarina, Florianópolis, 2016.

SOUSA, Leandro Gomes de. Redes sociais, mercado e cultura migratória: um estudo sobre fatores associados à mobilidade populacional na microrregião de Governador Valadares no século XXI. 154 f. 2016. Tese (Doutorado em Demografia) Universidade Federal de Minas Gerais, Belo Horizonte, 2016.

THURLER, Ana Liési. Migrações nacionais, gênero e relações sociais de dominação. Dimensões, Vitória, v. 26, p. 205-222, jan./ jun. 2011.

TRUZZI, Oswaldo. Redes em processos migratórios. Tempo Social, Revista de Sociologia da USP, São Paulo, v. 20, n. 1, p. 199-218, jan./ jun. 2008.

VASCONCELOS, Pedro. Redes de apoio familiar e desigualdade social: estratégias de classe. Análise Social, Lisboa, v. 37, n. 163, p. 507-544, 2002. 
WEISS, Robert Stuart. Learning from strangers: the art and method of qualitative interview studies. New York: The Free Press, 1994.

WENTZEL, Marina. O que faz o Brasil ter a maior população de domésticas do mundo. BBC News, São Paulo, 26 fev. 2018. Disponível em: https://www.bbc.com/portuguese/brasil-43120953. Acesso em: 10 dez. 2018.

YEATES, Nicola. Global care chains: a state-of-the-art review and future directions in care transnationalization research. Global Networks, Oxford, UK, v.12, n. 2, p. 135-154, 2012.

Recebido em: 12 de maio de 2020

Aceito em: 4 de agosto de 2020 